\title{
Usage of the standard and modified comet assay in assessment of DNA damage in human lymphocytes after exposure to ionizing radiation
}

\author{
Morana Mikloš, Goran Gajski, Vera Garaj - Vrhovac \\ Institute for Medical Research and Occupational Health, Mutagenesis Unit, Zagreb, Croatia
}

Background. Human organisms are extremely sensitive to ionizing radiation, which has the strong genotoxic effect on the DNA molecule. The aim of the present study was to detect the type of DNA damage and cell death caused by ionizing radiation as well as the sensitivity of the standard and modified comet assay. Methods. The effect of gamma radiation ( $0.1 \mathrm{~Gy}$ and $4 \mathrm{~Gy}$ ) on human lymphocytes was observed using the standard alkaline and Fpg-modified comet assay with ability to detect oxidized purines as well as with the DNA diffusion test.

Results. Parameters of the standard comet assay showed significantly higher values in samples exposed to $4 \mathrm{~Gy}$ than in samples exposed to radiation dose of $0.1 \mathrm{~Gy}$ and control sample. The Fpg-modified comet assay showed significantly higher values already at dose of $0.1 \mathrm{~Gy}$ as the result of oxidative DNA damage. The DNA diffusion test showed that gamma rays lead to apoptosis more often than to necrosis.

Conclusions. This observation suggests that the standard alkaline and Fpg-modified comet assays as well as the DNA diffusion test are reliable techniques for estimation of DNA damage and form of the cell death caused by gamma radiation in vitro. In addition Fpg-modified comet assay prove to be more sensitive for detection of gamma irradiation induced DNA damage than the standard assay.

Key words: human peripheral blood lymphocytes; ROS; gamma radiation; alkaline comet assay; Fpgmodified comet assay; diffusion test

\section{Introduction}

Ionizing radiation is nowadays omnipresent in human lives because of the increasing development of technology, industry

Received 21 January 2009

Accepted 19 March 2009

Correspondence to: dr. Vera Garaj-Vrhovac, Institute for Medical Research and Occupational Health, Mutagenesis Unit, Ksaverska cesta 2, 10000 Zagreb, Croatia. Tel. +385 14673 188; Fax. +385 14673 303; E-mail: vgaraj@imi.hr and medicine. People live and work near nuclear facilities and places of testing nuclear weapon and also use nuclear (gamma) radiation in medical purposes. In each case, human organism bears the strong genotoxic effect making the structure of the DNA molecule unstable and causing the genesis of many changes in it. ${ }^{1}$ The damage of the genetic material caused by ionizing radiation is one of the best precondition indicator for development of malign diseases such as breast, gall-bladder or thyroid can- 
cer. $^{2,3}$ Gamma radiation affects the DNA structure directly, causing strand breaks, or indirectly causing cleavage of the water molecules and damaging the DNA molecule by reactive oxygen species (ROS). ${ }^{4}$ Strand breaks and oxidative damage in the DNA causes further cell death in the form of apoptosis or necrosis. ${ }^{5}$ These changes can be examined at human lymphocytes using different cytogenetic techniques. The most frequently used cytogenetic techniques are the comet assay, micronucleus test, chromatid exchange test, chromosomal aberrations test and fluorescence in situ hybridization (FISH) test. ${ }^{6-10}$

The comet assay (SCGE; single cell gel electrophoresis) is a rapid, simple, visual and sensitive technique for measuring and analyzing DNA damage at the single cell level. ${ }^{6,11-17}$ This technique can be performed at the level of individual cells and requires a small number of cells per sample. Single cells can be used in in vivo and in vitro as well as in biomonitoring of population exposed to radiation or chemical mutagens. $6,18,19$ The comet assay detects single and double stranded breaks at the level of DNA molecule, sites of incomplete repair, alkali labile sites, DNA-DNA and DNAprotein cross-links. Besides, the comet assay can be used for detection of the level of the DNA fragmentation in apoptosis. ${ }^{17,20-22}$ In addition; particular enzymes such as formamidopyrimidine glycosilase can be used for detection of oxidative damage at the level of the DNA molecule caused by ROS. ${ }^{23-25}$

The DNA diffusion assay, a simple, sensitive, and reliable cytogenetic method is often used for quantification of apoptosis, is based on the principle that nuclear DNA of apoptotic cells have abundant alkalilabile sites and under alkaline conditions small pieces of DNA thus generates diffuse in agarose, giving the appearance of a halo if stained with a sensitive fluorescent dye. Apoptotic cells show a circular gradient of granular DNA with a dense central zone and a lighter and hazy outer zone, giving the overall appearance of a halo. ${ }^{26}$

Peripheral blood lymphocytes were exposed to gamma radiation doses of 0.1 Gy and 4 Gy in vitro. In that manner, the aim of this study was to detect the type of DNA damage caused by ionizing radiation. Considering that, two forms of the comet assay, standard alkaline and Fpg-modified were used. In addition, sensitivity of both techniques toward different doses of gamma radiation was measured. The DNA diffusion test was also used to detect the form of the cell death caused by gamma radiation.

\section{Materials and methods}

\section{Blood sampling}

The study was performed on peripheral blood samples obtained from a healthy female non-smoking donor (age 24 years). The donor was not exposed to ionizing radiation, vaccinated or used medicals for a year before blood sampling. Whole venous blood was collected under sterile conditions in heparinised vacutainer tubes (Becton Dickinson, NJ, USA) containing lithium heparin as anticoagulant. After collection, blood was divided into a large number of samples. All experiments were conducted on peripheral blood lymphocytes cultivated at $37^{\circ} \mathrm{C}$ in an atmosphere of $5 \% \mathrm{CO}_{2}$ in air.

\section{Exposure conditions}

The whole blood samples were irradiated with gamma radiation on the ice. As a source of radiation Gammacell 220 (Institute "Ruđer Bošković", Zagreb, Croatia) was used. Vacutainers (volume $5 \mathrm{~cm}^{3}$ ) containing blood samples were exposed to radiation doses defined as doses in the water, but irradiation was performed 
in the air. Samples were irradiated with radiation doses of $0.1 \mathrm{~Gy}$ and $4 \mathrm{~Gy}$ that is equal to radiation periods of $32.3 \mathrm{~s}$ and $23 \mathrm{~min}$ and $9 \mathrm{~s}$ at temperature of $21^{\circ} \mathrm{C}$. Significance of the absorbed dose was $3 \% .{ }^{27}$ To get homogenate samples, they were stirred after irradiation, cooled to $4{ }^{\circ} \mathrm{C}$, transported to the laboratory on ice and processed as quickly as possible.

\section{Determination of cell viability}

The indices of cell viability and necrosis were obtained from differential staining with acridine orange and ethidium bromide, using fluorescence microscopy. ${ }^{28}$ Lymphocytes were isolated using a modification of the Ficoll-Histopaque centrifugation method. ${ }^{29}$ The slides were prepared using $200 \mu \mathrm{l}$ of human peripheral blood lymphocytes and $2 \mu \mathrm{l}$ of stain (acridine orange and ethidium bromide, both diluted in PBS). A total of 100 cells were analyzed to determine the percentage of viable cells using an Olympus AX-70 microscope with $60 \times$ magnification and 515-560 nm fluorescence filters. The cells were classified according the following description: live cells with a functional membrane, with uniform green staining of the nucleus and necrotic cells with uniform red staining of the nucleus.

\section{The alkaline comet assay}

To evaluate DNA damage after irradiation and to test sensitivity of the technique towards gamma radiation the comet assay was carried out under alkaline conditions, basically as described by Singh et al. ${ }^{14}$ Fully frosted slides were covered with agarose (Sigma) containing the whole blood sample. The slides were then immersed for $1 \mathrm{~h}$ in lysis solution (2.5 M NaCl, $100 \mathrm{mM} \mathrm{Na} 2$ EDTA, $10 \mathrm{mM}$ Tris- $\mathrm{HCl}, 1 \%$ sodium sarcosinate (Sigma), $\mathrm{pH} 10$ ) with $1 \%$ Triton $\mathrm{X}-100$ (Sigma) and
10\% dimethyl sulfoxide (Kemika, Zagreb, Croatia). The slides were then placed on a horizontal gel electrophoresis tank. The unit was filled with electrophoresis buffer (0.3 MNaOH, $1 \mathrm{mMNa}_{2}$ EDTA; $\left.\mathrm{pH} 13\right)$ and the slides were placed in this alkaline buffer for $20 \mathrm{~min}$. Denaturation and electrophoresis were performed at $4{ }^{\circ} \mathrm{C}$ under dim light. Electrophoresis was carried out for $20 \mathrm{~min}$ at $25 \mathrm{~V}(300 \mathrm{~mA})$. After electrophoresis the slides were rinsed with neutralization buffer (0.4 M Tris-HCl, pH 7.5). Each slide was stained with ethidium bromide $(20 \mu \mathrm{g} /$ ml) and covered with a coverslip. The slides were then stored in sealed boxes at $4^{\circ} \mathrm{C}$ until analysis.

\section{Fpg-modified comet assay}

For evaluation of possible oxidative DNAdamaging effect of gamma radiation and to test the sensitivity of the technique, modified version of the comet assay was performed using an Fpg FLARE ${ }^{\mathrm{TM}}$ assay kit (Trevigen Inc, Gaithersburg, USA) with some modification. ${ }^{30}$ Within the kit the manufacturer provided all the reagents used. Fully-frosted microscopic slides were prepared. Each slide was covered with $1 \%$ normal melting point (NMP) agarose (Sigma). After solidification, the gel was scraped off the slide. The slides were then coated with $0.6 \%$ NMP agarose. A low melting point (LMP) agarose was melted and stabilized in a water bath at $37^{\circ} \mathrm{C}$. For each sample and control, $5 \mu$ l of cell homogenate was mixed with $100 \mu$ l of LMP agarose and placed on the slides. After 10 min of solidification on ice, the slides were covered with $0.5 \%$ LMP agarose. The slides were then immersed in a pre-chilled lysis solution and kept in a refrigerator at $2^{\circ} \mathrm{C}$ for $60 \mathrm{~min}$. Followed the immersion in the buffer, three times for $15 \mathrm{~min}$. After lysis, the slides were treated with $100 \mu \mathrm{l}$ of Fpg enzyme (1:500 in REC dilution buffer). The enzyme was di- 
luted right before use. Control slides were treated with $100 \mu \mathrm{l}$ of REC dilution buffer only. The slides were placed horizontally in a humidity chamber at $37{ }^{\circ} \mathrm{C}$ for $30 \mathrm{~min}$. All slides were then immersed in an alkali solution (0.3 M NaOH, $1 \mathrm{mM} \mathrm{Na} 2$ EDTA; $\mathrm{pH}$ 12.1) for $40 \mathrm{~min}$. Followed electrophoresis in a pre-chilled alkali solution (0.3 M NaOH, 1 mM Na ${ }_{2}$ EDTA; $\left.p H ~ 12.1\right)$ at $1 \mathrm{~V} / \mathrm{cm}$ for $20 \mathrm{~min}$. After electrophoresis, the slides were rinsed gently three times with neutralization buffer $(0.4 \mathrm{M}$ Tris- $\mathrm{HCl}$, $\mathrm{pH}$ 7.5) to remove excess alkali and detergents. Each slide was stained with ethidium bromide $(20 \mu \mathrm{g} / \mathrm{ml})$ and covered with a coverslip. Slides were stored at $4^{\circ} \mathrm{C}$ in sealed boxes until analysis.

\section{Comet capture and analysis}

A total of one hundred randomly captured comets from each slide were examined at 250x magnification using an epifluorescence microscope (Zeiss, Germany) connected through a black and white camera to an image analysis system (Comet Assay II; Perceptive Instruments Ltd., UK). The analysis did not include the edges and damaged parts of the gel as well as debris, superimposed comets, and comets without distinct head ("clouds", "hedgehogs", or "ghost cells").

Differences in the tail length, tail intensity and tail moment between samples obtained with standard alkaline comet assay (basic DNA damage) and Fpg-modified comet assay (total DNA damage) were considered as oxidative DNA damage in a single cell.

\section{DNA diffusion test}

For evaluation of the type of the cell death DNA diffusion assay was performed following the protocol described by Singh. ${ }^{12,31}$ The chemicals needed for the DNA dif- fusion assay were provided by the Sigma Chemical Company. Agarose precoated slides were made by spreading $50 \mathrm{ml}$ of $0.7 \%$ normal melting agarose on each slide and drying them at room temperature. Microgels were made on agarose-precoated slides by mixing $5 \mu \mathrm{l}$ of whole blood culture with $50 \mu \mathrm{l}$ of $0.7 \%$ high-resolution agarose and pipetting it onto the slide. The gel was immediately covered with a cover glass. The slides were coded and cooled on ice for $1 \mathrm{~min}$. The cover glasses were removed, and $200 \mathrm{ml}$ of $2 \%$ agarose solution was layered. After keeping the slides for $1 \mathrm{~min}$ on ice, the cover glasses were removed and the slides were immersed in a freshly made lysing solution (1.25 M NaCl, $1 \mathrm{mM}$ tetra sodium EDTA, $5 \mathrm{mM}$ Tris- $\mathrm{HCl} \mathrm{pH}$ $10,0.01 \%$ sodium lauroyl sarcosine, $0.2 \%$ DMSO freshly added, $0.3 \mathrm{M} \mathrm{NaOH}$ freshly added) for $10 \mathrm{~min}$ at room temperature. After lysis, the slides were twice immersed in a neutralising solution (50\% ethanol, 1 $\mathrm{mg} / \mathrm{ml}$ spermine, $20 \mathrm{mM}$ Tris- $\mathrm{HCl} \mathrm{pH} 7.4$ ) for $30 \mathrm{~min}$ at room temperature. The slides were air-dried and stored at room temperature. The slides were stained with ethidium bromide $(20 \mu \mathrm{g} / \mathrm{ml})$ and covered with a coverslip for $10 \mathrm{~min}$. 1000 lymphocytes per slide were analysed. Lymphocytes undergoing apoptosis or necrosis were distinguished from normal cells in accordance with the figures and instructions given by Singh. ${ }^{31}$ Apoptotic cell nuclei have a hazy or undefined outline without any clear boundary due to nucleosomal-sized DNA diffusing into the agarose. Necrotic cell nuclei are bigger and are poorly defined. They have a clear, defined outer boundary of the DNA halo and a relatively homogeneous halo appearance.

\section{Statistical analysis}

Each experimental set contained duplicated slides. The various parameters measured in 
the exposed and control groups were evaluated using Statistica 5.0 package (StaSoft, Tulsa, USA). Each sample was characterized for the extent of DNA damage by considering the mean \pm SE (standard error of the mean), median and range of the comet parameters. Multiple comparisons between groups were done by means of ANOVA on log-transformed data. Post-hoc analysis of differences was done by Scheffé test. As for the DNA diffusion test, values were analyzed using the chi-square test. The level of statistical significance was set at $P<0.05$.

\section{Results}

\section{Cell viability test}

The viability of the cells as determined by acridine orange and ethidium bromide, using fluorescence microscopy, was consistently above $89 \%$ in all the exposed samples and $100 \%$ in control samples. This is considered to be in acceptable range for conducting the comet assay. 32,33

\section{Comet assay and Fpg-modified comet assay}

Results of the standard alkaline comet assay are presented in the Table 1 . These results showed statistically significant increase of the mean values for all three parameters of the standard comet assay $(P<0.05)$ in the sample irradiated with the dose of $4 \mathrm{~Gy}$ in contrast to control sample and sample irradiated with the dose of 0.1 Gy. Sample irradiated with the dose of 0.1 Gy showed slightly increased values for all parameters measured but there were no significant differences in compare to the corresponding control (Figure 1).

Results of the Fpg-modified comet assay are presented in the Table 2 . These results showed statistically significant increase in all three parameters of modified comet assay $(P<0.05)$ for both irradiation doses in compare to the control sample (Figure 2).

Generally, the mean values of all three Fpg-modified comet assay parameters were significantly higher than of the standard comet assay. These findings suggest that the Fpg-modified comet assay is more sensitive to gamma irradiation than the standard comet assay.

\section{DNA diffusion test}

Percentage of apoptotic and necrotic cells gained for the diffusion test is presented in Table 3 whereas Figure 3 presents microphotographs of viable, apoptotic, and necrotic cells from the un-exposed sample and samples irradiated with gamma radiation. These results showed statistically significant increase $(P<0.05)$ of apoptotic cells in samples irradiated with the dose of 0.1 Gy and 4 Gy in comparison to the control sample. Significant increase in apoptotic cells was also found in sample irradiated with 4 Gy in comparison to the sample irradiated with $0.1 \mathrm{~Gy}$. Number of necrotic cells significantly increased only in sample irradiated with 4 Gy in comparison to the control sample, while statistically significant increase in comparison to the sample irradiated with the dose of 0.1 Gy was not present.

\section{Discussion}

Our goal was to test the sensitivity of different protocols for comet assay, and to evaluate the type of cell death caused by different doses of gamma radiation. This type of radiation is a potent carcinogen mainly due to it potential as oxidativeinduced damage agent. It produces variety of primary lesions in DNA such as single and double strand breaks, DNA-DNA 

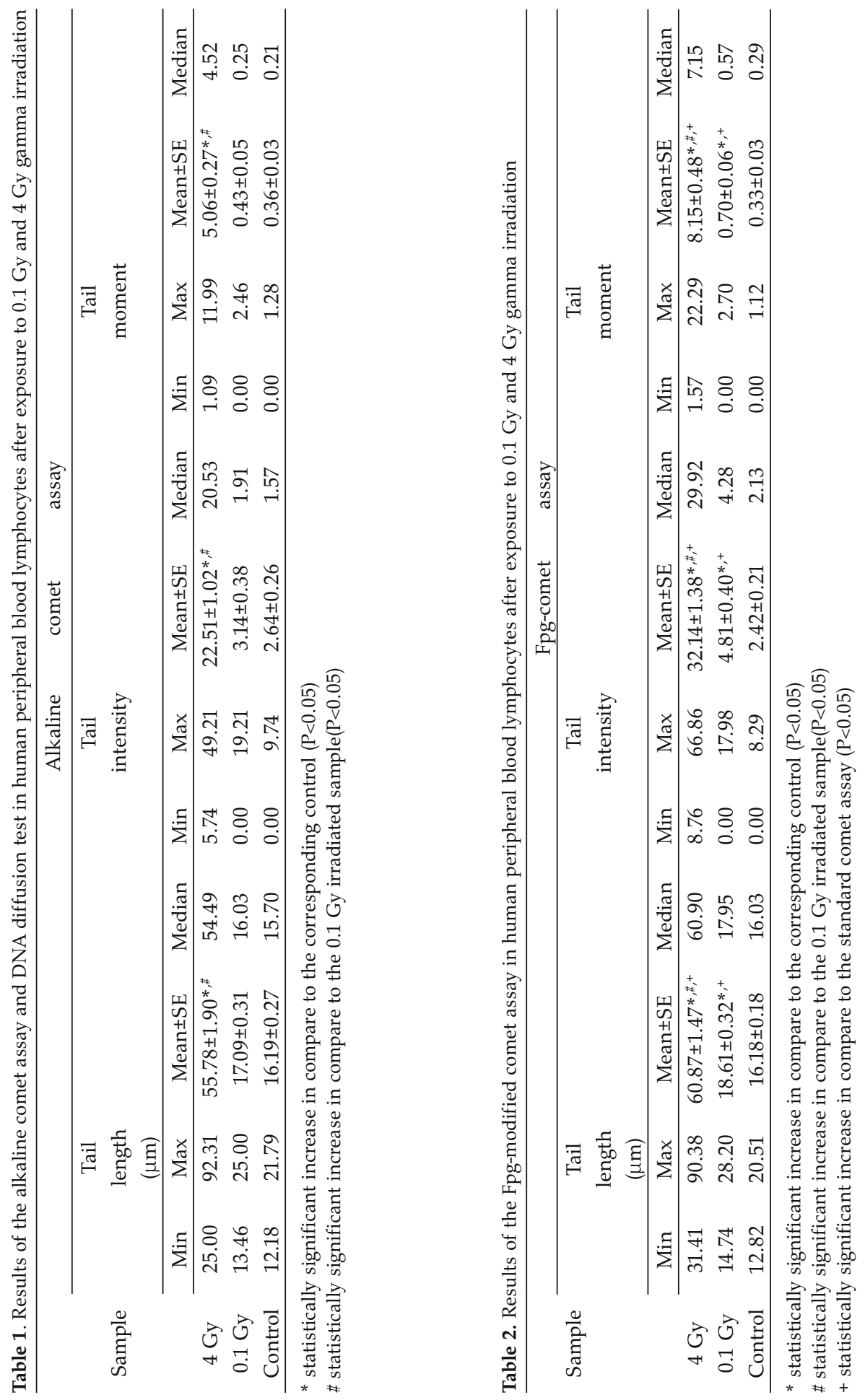

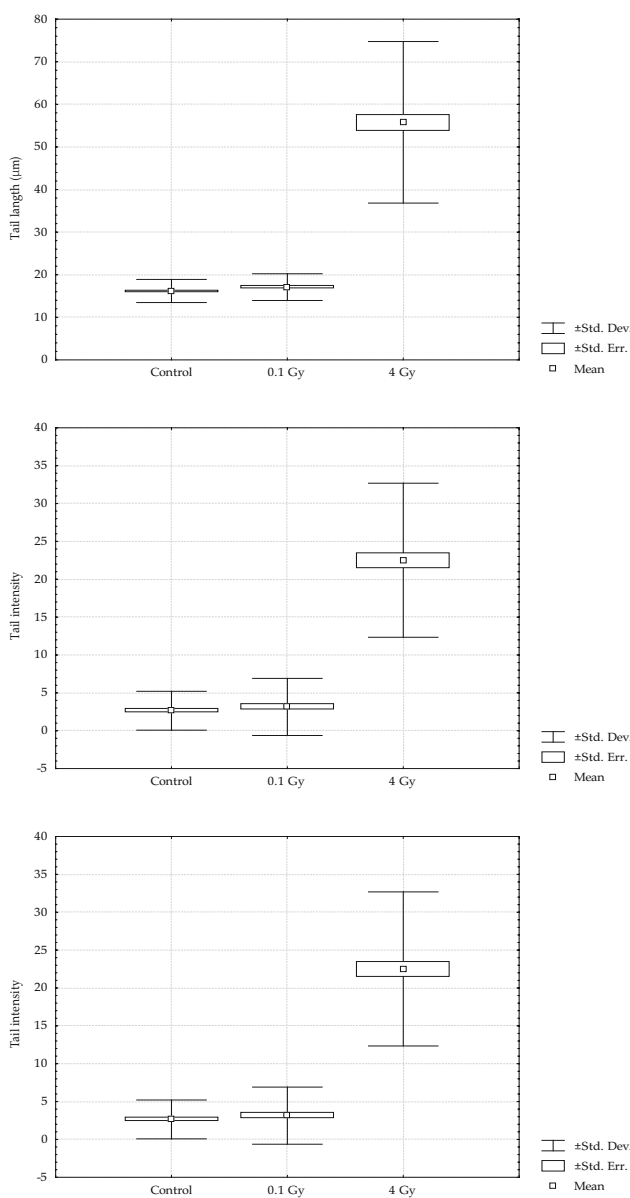

$\mp \pm$ Std. Dev.
$\square \pm$ Std. Err.

Figure 1. Parameters of the alkaline comet assay (tail length, tail intensity and tail moment), for human peripheral blood lymphocytes exposed to $0.1 \mathrm{~Gy}$ and 4 Gy gamma irradiation.

Table 3. Results of the DNA diffusion test in human peripheral blood lymphocytes after exposure to $0.1 \mathrm{~Gy}$ and 4 Gy gamma irradiation.

\begin{tabular}{ccc}
\hline & \multicolumn{2}{c}{ DNA diffusion test } \\
\hline Sample & Apoptosis & Necrosis \\
\cline { 2 - 3 } 4 Gy & $\%$ & $\%$ \\
\cline { 2 - 3 } 0.1 Gy & $4.90^{*}$, & $4.10^{*}$ \\
Control & $3.00^{*}$ & 2.50 \\
\hline
\end{tabular}

* statistically significant increase in compare to the corresponding control $(\mathrm{P}<0.05)$

\# statistically significant increase in compare to the 0.1 Gy irradiated sample $(\mathrm{P}<0.05)$
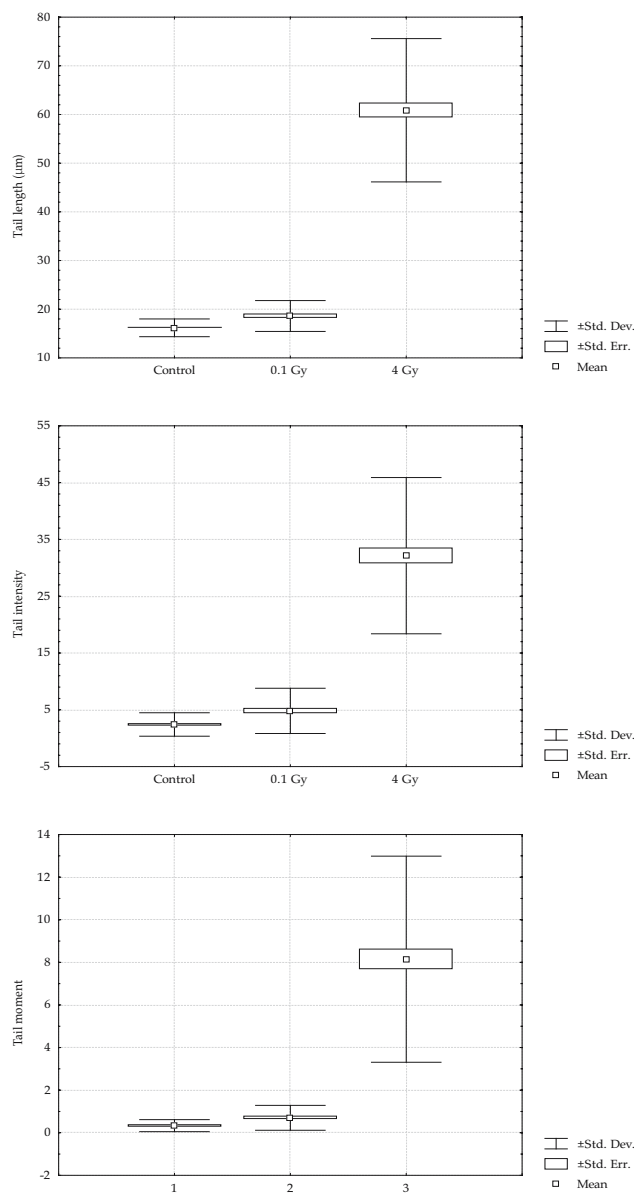

Figure 2. Parameters of the Fpg-modified comet assay (tail length, tail intensity and tail moment), for human peripheral blood lymphocytes exposed to $0.1 \mathrm{~Gy}$ and 4 Gy gamma irradiation.

and DNA-protein cross-links, alkali-labile sites and damage to purine and pyrimidine bases as well as oxidize bases and abasic sites. $^{34,35,36,37}$

In that manner, standard alkaline and Fpg-modified version of the comet assay were used as well as the DNA diffusion test to access whether this type of radiation induces apoptotic or necrotic cell death. Techniques used in this study showed genotoxic effect of gamma rays on DNA molecule of peripheral blood human lym- 

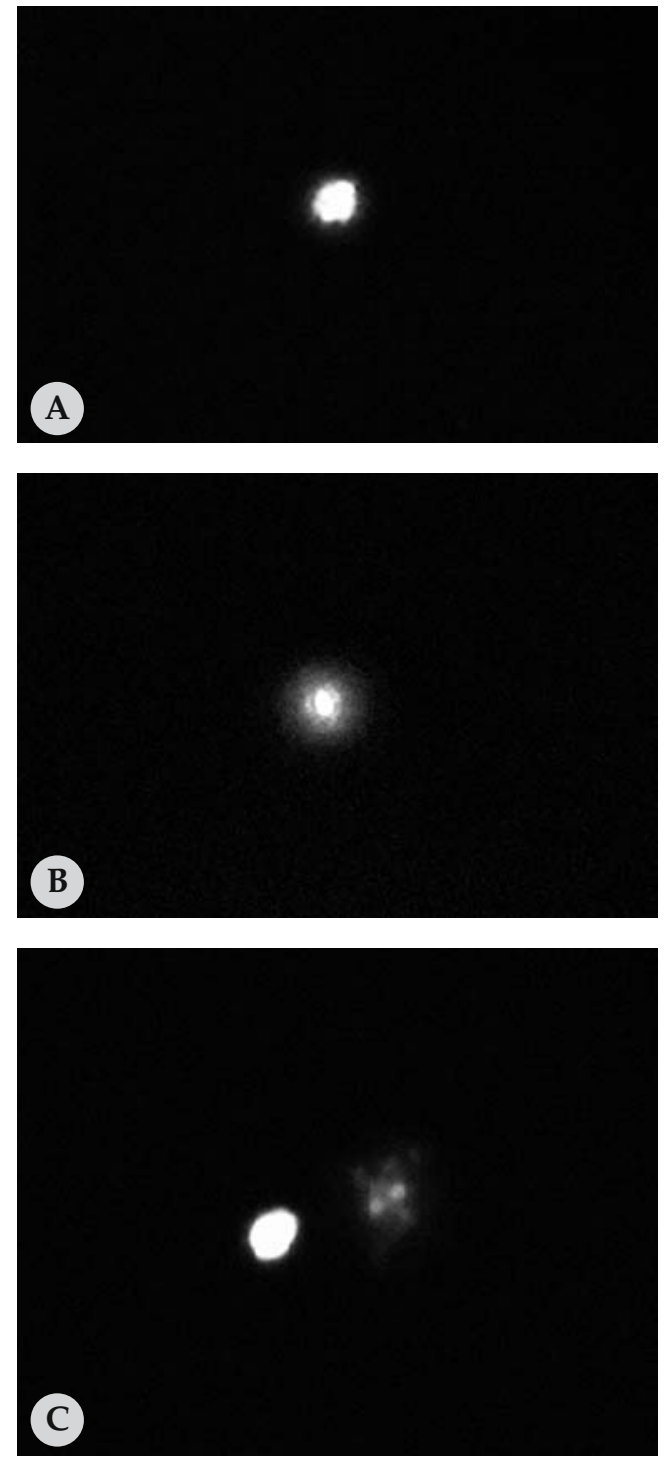

Figure 3. DNA diffusion microphotographs of viable lymphocytes from the un-exposed sample (A), and apoptotic (B) and necrotic (C) cells from samples irradiated with gamma radiation.

phocytes in vitro. With the standard alkaline comet assay increase in DNA damage was noticed in both exposure doses but it was significant only at higher dose of 4 Gy whereas at lower dose there were no statistically significant increase in neither of the standard comet assay parameters.
Usage of the Fpg-modified protocol showed significant increase in all the parameters measured at both exposure doses indicating that the modified version of this assay is capable to detect wider scale of DNA damage induced by gamma irradiation. In addition, with modified protocol it is possible to detect ROS mediated DNA damage, thus significant increase in modified comet parameters in comparison to the standard one suggests that gamma radiation did induce oxidative damage in DNA molecule in vitro.

Some of the previous studies also showed that the Fpg-modified version of the comet assay is more sensitive for detection of DNA damage than the standard alkaline one. ${ }^{18,22,24,38-41}$ According to that fact, scientists revealed that using the standard alkaline comet assay it is possible to detect damages at radiation doses from 5 cGy to 10 cGy ${ }^{42,43}$ and in some adapted experimental conditions (e.g. addition of the Fpg enzyme) it is possible to detect damages even at radiation doses of $0.6 \mathrm{cGy} .{ }^{44,45}$ The additional reason why the Fpg-modified comet assay is more sensitive than the standard alkaline one is that the Fpg enzyme helps to detect oxidative damage of the DNA molecule by cleavage of 8-oxodG, FaPyGua, FaPyAde and other ring-opened purines. ${ }^{46,47,48}$

In one of our previous research done on atorvastatin toxicity towards peripheral blood lymphocytes modified comet protocol also showed greater sensitivity in the manner of DNA damage. In that study all parameters obtained with the standard comet assay and Fpg-modified comet assay were significantly higher in the treated than in control lymphocytes, but the Fpgmodified protocol showed a significantly greater tail length, tail intensity, and tail moment in all treated lymphocytes than did the standard comet assay. ${ }^{18}$

Another comparison of the standard alkaline and Fpg-modified comet assay was made on leukocytes collected from Wistar 
rats after exposure to $915 \mathrm{MHz}$ microwave radiation. Both the standard and the Fpgmodified comet assay detected increased DNA damage in blood leukocytes of the exposed rats. The significant increase in Fpg-detected DNA damage in the exposed rats suggests that oxidative stress is likely to be responsible and that Fpg-modified protocol is much more sensitive than the standard one. These results are in compliance with our results because of the higher values obtained with Fpg-modified comet assay than with standard alkaline indicating oxidative DNA damage. ${ }^{39}$ Strand breaks and oxidative damage at the level of DNA molecule have further consequences for the cells. Depending on the kind and the level of the damage, these effects often lead to the cell death which appears in the form of apoptosis or necrosis. ${ }^{49}$ In our study this was evaluated by using the DNA diffusion test. Observing results, it was noticed that higher radiation dose increased the number of apoptotic cells in compare to the number of necrotic cells. That was because; gamma radiation damages the DNA molecule by producing reactive oxygen species more often than hitting the DNA molecule directly and causing strand breaks. These reactive oxygen species initiate cascade reactions in the cells witch leads to apoptosis, what makes apoptosis more frequent form of cell death than necrosis. ${ }^{50}$

\section{Conclusion}

In this study correlation between different protocols of the comet assay was made suggesting that Fpg-modified version is more sensitive to gamma radiation by virtue of measuring oxidative DNA damage in addition to basal DNA strand breaks. Moreover, evaluation of the type of cell death was made using DNA diffusion test indicating that gamma rays more often leads to apoptosis. Results obtained lead to the same conclusion that gamma radiation affects the DNA molecule by ROS that are most frequent product of the gamma radiation effect. Human peripheral blood lymphocytes proved to be sensitive to ionizing radiation depending on the radiation dose and are suitable biomarkers for this type of research.

\section{Acknowledgements}

This investigation was supported by the Croatian Ministry of Science, Education and Sports (grant No. 0022-0222148-2125).

\section{References}

1. Mettler FA, Voelz GL. Major radiation exposure-what to expect and how to respond. $N$ Engl J Med 2002; 346: 1554-61.

2. Beir V. Health effects of exposure to low levels of ionizing radiation. Committee on the biological effects of ionizing radiation. Washington, DC: National Academy Press; 1990.

3. Cooke M, Evans M. Oxidative damage to DNA in non-malignant disease: biomarker or biohazard? Genome Dyn 2006; 1: 53-66.

4. Ito K, Takubo K, Satoh H, Matsuoka S, Ohmura M, Naka K et al. Regulation of reactive oxygen species by Atm is essential for proper response to DNA double-strand breaks in lymphocytes. J Immunol 2007; 178: 103-10.

5. Higuchi Y. Chromosomal DNA Fragmentation in apoptosis and necrosis induced by oxidative stress. Biochem Pharmacol 2003; 66: 1527-35.

6. Faust F, Kassie F, Knausmüller S, Boedecker RH, Mann M, Mersch-Sundermann V. The use of the alkaline comet assay with lymphocytes in human biomonitoring studies. Mutat Res 2003; 566: 20929.

7. Fenech M. The micronucleus assay determination of chromosomal level DNA damage. Methods $\mathrm{Mol}$ Biol 2008; 410: 185-216. 
8. Willson DM, Thompson LH. Molecular mechanisms of sister-chromatid exchange. Mutat Res 2006; 616: 11-23.

9. Mateuca R, Lombaert N, Aka PV, Decodier I, Kirsch-Volders M. Chromosomal changes: induction, detection methods and applicability in human biomonitoring. Biochimie 2006; 88: 1515-31.

10. Leonard A, Rueff J, Gerber GB, Leonard ED. Usefulness and limits of biological dosimetry based on cytogenetic methods. Radiat Prot Dosimetry 2005; 115: 448-54.

11. Cotelle S, Ferrard JF. Comet assay in genetic ecotoxicology: a review. Environ Mol Mutagen 1999; 34: 246-55.

12. Singh NP. A simple method for accurate estimation of apoptotic cells. Exp Cell Res 2000; 256: 328-37.

13. Møller P. The alkaline comet assay: towards validation in biomonitoring of DNA damaging exposures. Basic Clin Pharmacol Toxicol 2006; 98: 336-45.

14. Singh NP, McCoy MT, Tice RR, Schneider LL. A simple technique for quantitation of low levels of DNA damage in individual cells. Exp Cell Res 1988; 175: 184-91.

15. Tice RR, Andrews PW, Hirai O, Singh NP. The single cell gel (SCG) assay: an electrophoretic technique for the detection of DNA damage in individual cells. In Witmer CM, Snyder RR, Hollow DJ, Kalf GF, Kocsis JJ, Sipes JG, editor. Biological Reactive Intermediates. IV. Molecular and Cellular Effects and their Impact on Human Health. New York: Plenum Press; 1990. p. 157-64.

16. Fairbairn DW, Olive PL, O'Neill KL. The comet assay: a comprehensive review. Mutat Res 1995; 33: 37-59.

17. Olive PL. DNA damage and repair in individual cells: applications of the comet assay in radiobiology. Int J Radiat Biol 1999; 75: 395-405.

18. Garaj-Vrhovac V, Kopjar N, Ražem D, Vekić B, Miljanic S, Ranogajec-Komor M. Application of the alkaline comet assay in biodosimetry: assessment of in vivo DNA damage in human peripheral leukocytes after a gamma radiation incident. Radiat Prot Dosimetry 2002; 98(4): 407-16.

19. Gajski G, Garaj-Vrhovac V, Orescanin V. Cytogenetic status and oxidative DNA-damage induced by atorvastatin in human peripheral blood lymphocytes: Standard and Fpg-modified comet assay. Toxicol Appl Pharmacol 2008; 231: 85-93.
20. Piperakis SM, Visvardis EE, Tassiou AM. Comet assay for nuclear DNA damage. Methods Enzymol 1999; 300: 184-94.

21. Collins AR. The comet assay for DNA damage and repair: principles, applications, and limitations. Mol Biotechnol 2004; 26: 249-62.

22. Husseini GA, O'Neill KL, Pitt WG. The comet assay to determine the mode of cell death for the ultrasonic delivery of doxorubicin to human leukemia (HL-60 Cells) from Pluronic P105 micelles. Technol Cancer Res Treat 2005; 4: 707-99.

23. Collins AR, Duthie SJ, Dobson VL. Direct enzymatic detection of endogenous oxidative base damage in human lymphocyte DNA. Carcinogenesis 1993; 14: 1733-5.

24. Krokan HE, Standal R, Slupphaug G. DNA glycosylases in the base excision repair. Biochem J 1997; 325: 1-16.

25. Speit G, Schütz P, Bonzheim I, Trenz K, Hoffman $\mathrm{H}$. Sensitivity of the FPG protein towards alkylation damage in the comet assay. Toxicol Lett 2003; 146: 151-8.

26. Singh NP. Apoptosis Assessment by the DNA diffusion assay. Methods Mol Med 2005; 111: 55-67.

27. Miljanić S, Ražem D, Ranogajec-Komor M. Dosimetric calibration of an annular 60 Co gamma-ray source. J Radioanal Nucl Chem 1994; 185: 101-8.

28. Duke RC, Cohen JJ. Morphological and biochemical assays of apoptosis. In: Coligan JE, Kruisbeal AM, editor. Current Protocols in Immunology. New York: John Willey \& Sons; 1992. p. 1-3.

29. Singh NP. Microgels for estimation of DNA strand breaks, DNA protein crosslinks and apoptosis. Mutat Res 2000; 455: 111-27.

30. Comet Assay interest group website: http://cometassay.com/

31. Singh NP. Apoptosis by DNA diffusion assay. In: Blumenthal R, editor. Methods in Molecular Medicine-Chemosensitivity, New York: Humana Press; 2003. p. 78-94.

32. Handerson L, Wolfreys A, Fedyk J, Bourner C, Windebank S. The ability of the Comet assay to discriminate between genotoxins and cytotoxins. Mutagenesis 1998; 13: 89-94. 
33. Tice RR, Agurell E, Anderson D, Burlinson B, Hartmann A, Kobayashi H. Single cell Gell/Comet Assay: guidelines for in vitro and in vivo genetic toxicology testing. Environ Mol Mutagen 2000; 35: 206-21.

34. Cadet J, Delatour T, Douki T, Gasparutto D, Pouget JP, Ravanat JL, Sauvaigo S. Hydroxyl radicals and DNA base damage. Mutat Res 1999; 424: 9-21.

35. Đurinec M, Želježić D, Garaj-Vrhovac V. Phytohaemagglutinin as a modulator of DNA repair measured by chromosome aberration analysis in micronucleus assay in ionizing radiation biodosimetry. Radiol Oncol 2006; 40: 43-9.

36. Garaj-Vrhovac V, Želježić D. Comet assay in the assessment of the human genome damage induced by -radiation in vitro. Radiol Oncol 2004; 38: 43-7.

37. Sudprasert W, Navasumrit P, Ruchirawat M. Effects of low-dose gamma radiation on DNA damage, chromosomal aberration and expression of repair genes in human blood cells. Int J Hyg Environ Health 2006; 209: 503-11.

38. Domijan AM, Želježić D, Kopjar N, Peraica M. Standard and Fpg-modified comet assay in kidney cells of ochratoxin A- and fumonisin $\mathrm{B}_{1}$-treated rats. Toxicology 2006; 222: 53-9.

39. Garaj-Vrhovac V, Gajski G, Trošić I, Pavičić I. Evaluation of basal DNA damage and oxidative stress in Wistar rat leukocytes after exposure to microwave radiation Toxicology 2009; 259: 17-12.

40. Fracasso ME, Doria D, Franceschetti P, Perbellini L, Romeo L. DNA damage and repair capacity by comet assay in lymhocytes of white-collar active smokers and passive smokers (non- and ex-smokers) at workplace. Toxicol Lett 2006; 167: 131-41.

41. Rössler U, Hornhardt S, Seidl C, Müller-Laue E, Walsh L, Panzer W et al. The sensitivity of the alkaline comet assay in detecting DNA lesions induced by $x$-rays, gamma rays and alpha particles. Radiat Prot Dosimetry 2006; 122: 154-9.

42. Tice RR. The single cell gel/comet assay: a microgel electrophoresis technique for the detection of DNA damage and repair in individual cells. In: Philips DH, Venitt S, editor. Environmental mutagenesis. Oxford, UK: Bios Scientific Publishers; 1995. p. 315-39.

43. Verbeek F, Koppen G, Schaeken B, Verschaeve L. Automated detection of irradiated food with the comet assay. Radiat Prot Dosimtery 2007; 128: 421-6.
44. Malyapa RS, Bi C, Ahern EW, Roti Roti JL. Detection of DNA damage by the alkaline comet assay after exposure to low-dose gamma radiation. Radiat Res 1998; 149: 396-400.

45. Collins A, Dusinská M. Detection of oxidised purines and UV-induced photoproducts in DNA of single cells, by inclusion of lesion specific enzymes in the comet assay. Altern Lab Anim 1996; 24: 405-11.

46. Karakaya A, Jaruga P, Bohr VA, Grollman AP, Dizdaroglu M. Kinetics of excision of purine lesions from DNA by Escherichia coli Fpg protein. Nucleic Acids Res 1997; 25: 474-9.

47. Smith CA, Williams GT. Molecular regulation of apoptosis: genetic control on cell death. Cel. 2006; 74: 777-9.

48. Dennog C, Hartmann A, Frey G, Speit G. Detection of DNA damage after hyperbaric oxygen (HBO) therapy. Mutagenesis 1996; 11: 605-9.

49. Gichner T, Mukherjee A, Wagner E, Plewa MJ. Evaluation of the nuclear DNA diffusion assay to detect apoptosis and necrosis. Mutat Res 2005; 586: $38-46$

50. Mishra KP. Cell membrane oxidative damage induced by gamma-radiation and apoptotic sensitivity. J Environ Pathol Toxicol Oncol 2004; 23: 61-6. 